\title{
MOTOR ABILITIES: PECULIARITIES OF STRENGTH EFFORT ASSESSMENT IN BOYS AGED 11-13
}

\author{
Ivashchenko O.V. ${ }^{1}$, Cieślicka Mirosława ${ }^{2}$, Nosko M.O. ${ }^{3}$, Malyshev D. A. ${ }^{4}$ \\ ${ }^{1,4}$ H.S. Skovoroda Kharkiv National Pedagogical University \\ ${ }^{2}$ Collegium Medicum: Bydgoszcz, Kujawsko Pomorskie \\ ${ }^{3}$ Taras Shevchenko National University of "Chernihiv Collegium"
}

Corresponding Author: Ivashchenko O.V., e-mail: olga@tmfv.com.ua

Accepted for Publication: March 20, 2019

Published: March 25, 2019

DOI:10.17309/tmfv.2019.1.05

\begin{abstract}
The purpose of the study is to determine the peculiarities of strength effort assessment in boys aged $11-13$.

Materials and methods. The study participants were boys aged 11 years $(n=22), 12$ years $(n=31), 13$ years $(n=33)$. The children and their parents were fully informed about all the features of the study and gave their consent to participate in the experiment. The paper used methods of scientific literature analysis, testing, methods of mathematical statistics. The study assessed the right hand effort at $1 / 3,1 / 2,2 / 3$ of the maximum. The assessment error was analyzed. To determine the peculiarities of strength effort assessment, the study used a t-test for paired observations and a t-test for independent samples.

Results. The analysis of the ability for strength effort assessment in the boys aged 11 and 13 showed that there are no statistically significant differences between the boys of this age. The boys demonstrate the best assessment of effort at $2 / 3$ of the maximum. There are no statistically significant differences in the levels of development of the hand maximum strength $(p>0.05)$. The study has not found statistically significant differences in the levels of development of the ability for strength effort assessment in the boys aged 11-13 $(p>0.05)$. The boys of this age demonstrate the best assessment of effort at $2 / 3$ of the maximum. A comparative analysis of the ability for strength effort assessment in the boys aged 12 and 13 did not reveal statistically significant differences $(p>0.05)$. The boys of this age demonstrate the best assessment of effort at $2 / 3$ of the maximum.

The boys aged 11-13 show the best assessment of effort reproduction at $2 / 3$ of the maximum $(p<0.05)$. There is no statistically significant age-related dynamics in strength effort assessment in the boys aged 11-13. The correlation between the effort reproductions at $1 / 3,1 / 2$ and $2 / 3$ of the maximum is not statistically significant.

Conclusions. In the process of physical education of boys aged 11-13, special attention should be paid to the development of motor control ability as the component of coordination training of schoolchildren. Keywords: movement coordination, strength effort, motor control, boys aged 11-13.
\end{abstract}

\section{Introduction}

One of the tasks of school physical education is to develop motor abilities in children and adolescents (Nosko, Iermakov \& Harkusha, 2010; Krutsevych, 2000). The research papers by Farfel (2011), Ivashchenko (2016) highlight the multifactorial structure of motor abilities in schoolchildren.

Movement coordination is viewed as one of the basic abilities that can be developed in school age

(C) Ivashchenko O.V., Cieślicka Mirosława, Nosko M.O., Malyshev D. A., 2019.
(Balsevich, 2000; Ilin, 2003; Serhiienko, Chekmarova \& Khadzhynov, 2012; Ivashchenko, O.B., 2016).

Researchers found that the level of coordination abilities development influences the effectiveness of teaching motor actions (Liakh, 2000, 2001; Khudolii, 2008; Ivashchenko, Khudolii, Iermakov, Lochbaum, Cieślicka, Zukow, Nosko \& Yermakova, 2017).

The importance and practical significance of studying kinesthetic sensitivity is indicated in papers by Li, Su, Fu and Pickett (2015), Brink and Jacobs (2011), Morash, Pensky, Alfaro and McKerracher (2012). Brink et al. (2011) emphasize the importance of developing kinesthetic sensitivity of hands in the school educational 
process. Data obtained by Morash et al. (2012) from the study of spatial abilities of the blind confirm that motor control indicators are an important aspect in motor skills development.

An important element in coordination abilities development is the availability of informative pedagogical control indicators (Krutsevych, Vorobiov \& Bezverkhnia, 2011; Ivashchenko \& Kapkan, 2016; Bodnar \& Andres, 2016) and the knowledge of peculiarities of teaching methods (Liakh, 2000; Khudolii, 2008; Ivashchenko, 2016). The methodology of pedagogical control applies multidimensional mathematical and statistical methods of analysis (Lopatiev, Ivashchenko, Khudolii, Pjanylo, Chernenko \& Yermakova, 2017; Ivashchenko, Khudolii, Iermakov, Prykhodkon \& Cieslicka, 2018).

Coordination abilities have a multifactorial structure (Ilin, 2003; Ivashchenko, Khudolii, Iermakov, Prykhodko \& Cieslicka, 2018). Motor control ability plays an important role in the structure of movement coordination (Liakh, 2000; Khudolii, 2008; Ivashchenko, 2016). Muscular strength is the basis for demonstrating schoolchildren's motor abilities, and the ability to assess muscular effort is fundamental to evaluating the spatial and temporal characteristics of movement (Khudolii, 2008; Khudolii \& Ivashchenko, 2014). The level of motor control ability positively impacts the effectiveness of motor skills development in children and adolescents (Farfel, 2011; Ivashchenko, 2016).

The analysis of scientific literature revealed the need for further research on the peculiarities of strength effort assessment.

The purpose of the study is to determine the peculiarities of strength effort assessment in boys aged $11-13$.

\section{Materials and methods}

Study participants. The study participants were boys aged 11 years $(n=22), 12$ years $(n=31), 13$ years $(n=33)$. The children and their parents were fully informed about all the features of the study and gave their consent to participate in the experiment.

Study organization. The paper used methods of scientific literature analysis, testing, methods of mathematical statistics.

Testing procedure. Strength effort assessment. Equipment: dynamometer, calculator. Testing: the right hand maximum strength was measured for each participant. After that, they were asked to perform the following effort that equals to:

$1 / 3$ of maximum strength;

$1 / 2$ of maximum strength;

$2 / 3$ of maximum strength;

The result in $\mathrm{kg}$ was recorded in the protocol. The error of the produced effort was calculated in percentage. To determine the maximum effort, the testees made two attempts. The best result was recorded. The dosed effort was performed once.

Statistical analysis. To determine the peculiarities of strength effort assessment, the study used a t-test for paired observations and a t-test for independent samples.

The study protocol was approved by the Ethical Committee of the University. In addition, the children and their parents or legal guardians were fully informed about all the features of the study, and a signed informedconsent document was obtained from all the parents.

\section{Results}

Table 1 shows the results of comparative analysis of the levels of ability for strength effort assessment in the boys aged 11 and 13. By all indicators, there are no statistically significant differences between the boys of this age. The boys show the best assessment of effort at $2 / 3$ of maximum strength. There are no statistically significant differences in the levels of development of the hand maximum strength $(p>0.05)$. The study has not found statistically significant differences in the levels of development of the ability for strength effort assessment in the boys aged 11 and $13(p>0.05)$, the

Table 1. Results of analysis of the ability for strength effort assessment in the boys aged 11 and 12

\begin{tabular}{|c|c|c|c|c|c|c|c|}
\hline Tests & Age & $\mathbf{N}$ & Mean & Std. Deviation & Mean difference & $\mathbf{t}$ & $\mathbf{P}$ \\
\hline \multirow{2}{*}{ Hand maximum strength } & 11 & 22 & 30.45 & 9.33 & \multirow{2}{*}{-1.90} & \multirow{2}{*}{-.740} & \multirow{2}{*}{-.740} \\
\hline & 12 & 31 & 32.35 & 9.13 & & & \\
\hline \multirow{2}{*}{ Effort at $1 / 3$ of maximum strength, $\%$} & 11 & 22 & 30.94 & 12.05 & \multirow[b]{2}{*}{2.02} & \multirow[b]{2}{*}{.624} & \multirow[b]{2}{*}{.535} \\
\hline & 12 & 31 & 28.92 & 11.24 & & & \\
\hline \multirow{2}{*}{ Effort at $1 / 2$ of maximum strength, $\%$} & 11 & 22 & 20.35 & 9.79 & \multirow{2}{*}{-0.21} & \multirow{2}{*}{-.075} & \multirow{2}{*}{.940} \\
\hline & 12 & 31 & 20.56 & 10.22 & & & \\
\hline \multirow{2}{*}{ Effort at $2 / 3$ of maximum strength, $\%$} & 11 & 22 & 16.70 & 9.58 & \multirow{2}{*}{1.49} & \multirow{2}{*}{.582} & \multirow{2}{*}{.563} \\
\hline & 12 & 31 & 15.21 & 8.94 & & & \\
\hline
\end{tabular}


Table 2. Results of analysis of the ability for strength effort assessment in the boys aged 11 and 13

\begin{tabular}{|c|c|c|c|c|c|c|c|}
\hline Tests & Age & $\mathbf{N}$ & Mean & Std. Deviation & Mean difference & $\mathbf{t}$ & $\mathbf{P}$ \\
\hline \multirow{2}{*}{ Hand maximum strength } & 11 & 22 & 30.45 & 9.33 & \multirow{2}{*}{2.06} & \multirow{2}{*}{.892} & \multirow{2}{*}{.376} \\
\hline & 13 & 33 & 28.39 & 7.71 & & & \\
\hline \multirow{2}{*}{ Effort at $1 / 3$ of maximum strength, $\%$} & 11 & 22 & 30.94 & 12.05 & \multirow{2}{*}{-0.62} & \multirow{2}{*}{-.181} & \multirow{2}{*}{.857} \\
\hline & 13 & 33 & 31.56 & 12.63 & & & \\
\hline \multirow{2}{*}{ Effort at $1 / 2$ of maximum strength, $\%$} & 11 & 22 & 20.35 & 9.79 & \multirow{2}{*}{-1.89} & \multirow{2}{*}{-.737} & \multirow{2}{*}{.464} \\
\hline & 13 & 33 & 22.24 & 9.00 & & & \\
\hline \multirow{2}{*}{ Effort at $2 / 3$ of maximum strength, $\%$} & 11 & 22 & 16.70 & 9.58 & \multirow{2}{*}{2.12} & \multirow{2}{*}{.944} & \multirow{2}{*}{.349} \\
\hline & 13 & 33 & 14.58 & 7.09 & & & \\
\hline
\end{tabular}

Table 3. Results of analysis of the ability for strength effort assessment in the boys aged 12 and 13

\begin{tabular}{|c|c|c|c|c|c|c|c|}
\hline Tests & Age & $\mathbf{N}$ & Mean & Std. Deviation & Mean difference & $\mathbf{t}$ & $\mathbf{P}$ \\
\hline \multirow{2}{*}{ Hand maximum strength } & 12 & 31 & 32.35 & 9.13 & \multirow{2}{*}{3.96} & \multirow{2}{*}{1.879} & \multirow{2}{*}{.065} \\
\hline & 13 & 33 & 28.39 & 7.71 & & & \\
\hline \multirow{2}{*}{ Effort at $1 / 3$ of maximum strength, $\%$} & 12 & 31 & 28.92 & 11.24 & \multirow{2}{*}{-2.64} & \multirow{2}{*}{-.879} & \multirow{2}{*}{.383} \\
\hline & 13 & 33 & 31.56 & 12.63 & & & \\
\hline \multirow{2}{*}{ Effort at $1 / 2$ of maximum strength, $\%$} & 12 & 31 & 20.56 & 10.22 & \multirow[b]{2}{*}{-1.68} & \multirow[b]{2}{*}{-.699} & \multirow[b]{2}{*}{.487} \\
\hline & 13 & 33 & 22.24 & 9.00 & & & \\
\hline \multirow{2}{*}{ Effort at $2 / 3$ of maximum strength, $\%$} & 12 & 31 & 15.20 & 8.94 & \multirow{2}{*}{0.62} & \multirow{2}{*}{.313} & \multirow{2}{*}{.757} \\
\hline & 13 & 33 & 14.58 & 7.09 & & & \\
\hline
\end{tabular}

Table 4. Results of analysis of the peculiarities of strength effort assessment in the boys aged $11(\mathrm{n}=22)$

\begin{tabular}{|c|c|c|c|c|c|c|}
\hline & Tests & Mean & $\begin{array}{c}\text { Std. Error } \\
\text { mean }\end{array}$ & Difference & $\mathbf{t}$ & $\mathbf{P}$ \\
\hline \multirow{2}{*}{ Pair 1} & Effort at $1 / 3$ of maximum strength, $\%$ & 30.94 & 2.57 & \multirow{2}{*}{10.59} & \multirow{2}{*}{3.038} & \multirow{2}{*}{.006} \\
\hline & Effort at $1 / 2$ of maximum strength, $\%$ & 20.35 & 2.09 & & & \\
\hline \multirow{2}{*}{ Pair 2} & Effort at $1 / 3$ of maximum strength, $\%$ & 30.94 & 2.57 & \multirow{2}{*}{14.23} & \multirow{2}{*}{4.292} & \multirow{2}{*}{.000} \\
\hline & Effort at $2 / 3$ of maximum strength, $\%$ & 16.70 & 2.04 & & & \\
\hline \multirow{2}{*}{ Pair 3} & Effort at $1 / 2$ of maximum strength, $\%$ & 20.35 & 2.09 & \multirow{2}{*}{3.64} & \multirow{2}{*}{1.472} & \multirow{2}{*}{.156} \\
\hline & Effort at $2 / 3$ of maximum strength, $\%$ & 16.70 & 2.04 & & & \\
\hline
\end{tabular}

Table 5. Results of analysis of the peculiarities of strength effort assessment in the boys aged $12(\mathrm{n}=31)$

\begin{tabular}{|c|c|c|c|c|c|c|}
\hline & Tests & Mean & $\begin{array}{c}\text { Std. Error } \\
\text { mean }\end{array}$ & Difference & $\mathbf{t}$ & $\mathbf{P}$ \\
\hline \multirow{2}{*}{ Pair 1} & Effort at $1 / 3$ of maximum strength, $\%$ & 28.92 & 2.02 & \multirow{2}{*}{8.36} & \multirow{2}{*}{2.890} & \multirow{2}{*}{.007} \\
\hline & Effort at $1 / 2$ of maximum strength, $\%$ & 20.56 & 1.85 & & & \\
\hline \multirow{2}{*}{ Pair 2} & Effort at $1 / 3$ of maximum strength, $\%$ & 28.92 & 2.02 & \multirow{2}{*}{13.72} & \multirow{2}{*}{6.085} & \multirow{2}{*}{.000} \\
\hline & Effort at $2 / 3$ of maximum strength, $\%$ & 15.21 & 1.61 & & & \\
\hline \multirow{2}{*}{ Pair 3} & Effort at $1 / 2$ of maximum strength, $\%$ & 20.56 & 1.84 & \multirow{2}{*}{5.35} & \multirow{2}{*}{2.246} & \multirow{2}{*}{.032} \\
\hline & Effort at $2 / 3$ of maximum strength, $\%$ & 15.21 & 1.61 & & & \\
\hline
\end{tabular}


Table 6. Results of analysis of the peculiarities of strength effort assessment in the boys aged $13(\mathrm{n}=33)$

\begin{tabular}{|c|c|c|c|c|c|c|}
\hline & Tests & Mean & $\begin{array}{c}\text { Std. Error } \\
\text { mean }\end{array}$ & Difference & $\mathbf{t}$ & $\mathbf{P}$ \\
\hline \multirow[b]{2}{*}{ Pair 1} & Effort at $1 / 3$ of maximum strength, $\%$ & 31.56 & 2.2 & \multirow{2}{*}{9.32} & \multirow{2}{*}{3.517} & \multirow{2}{*}{.001} \\
\hline & Effort at $1 / 2$ of maximum strength, $\%$ & 22.24 & 1.57 & & & \\
\hline \multirow{2}{*}{ Pair 2} & Effort at $1 / 3$ of maximum strength, $\%$ & 31.56 & 2.20 & \multirow{2}{*}{16.97} & \multirow{2}{*}{6.960} & \multirow{2}{*}{.000} \\
\hline & Effort at $2 / 3$ of maximum strength, $\%$ & 14.58 & 1.24 & & & \\
\hline \multirow{2}{*}{ Pair3 } & Effort at $1 / 2$ of maximum strength, $\%$ & 22.24 & 1.57 & \multirow{2}{*}{7.66} & \multirow{2}{*}{3.653} & \multirow{2}{*}{.001} \\
\hline & Effort at $2 / 3$ of maximum strength, $\%$ & 14.58 & 1.24 & & & \\
\hline
\end{tabular}

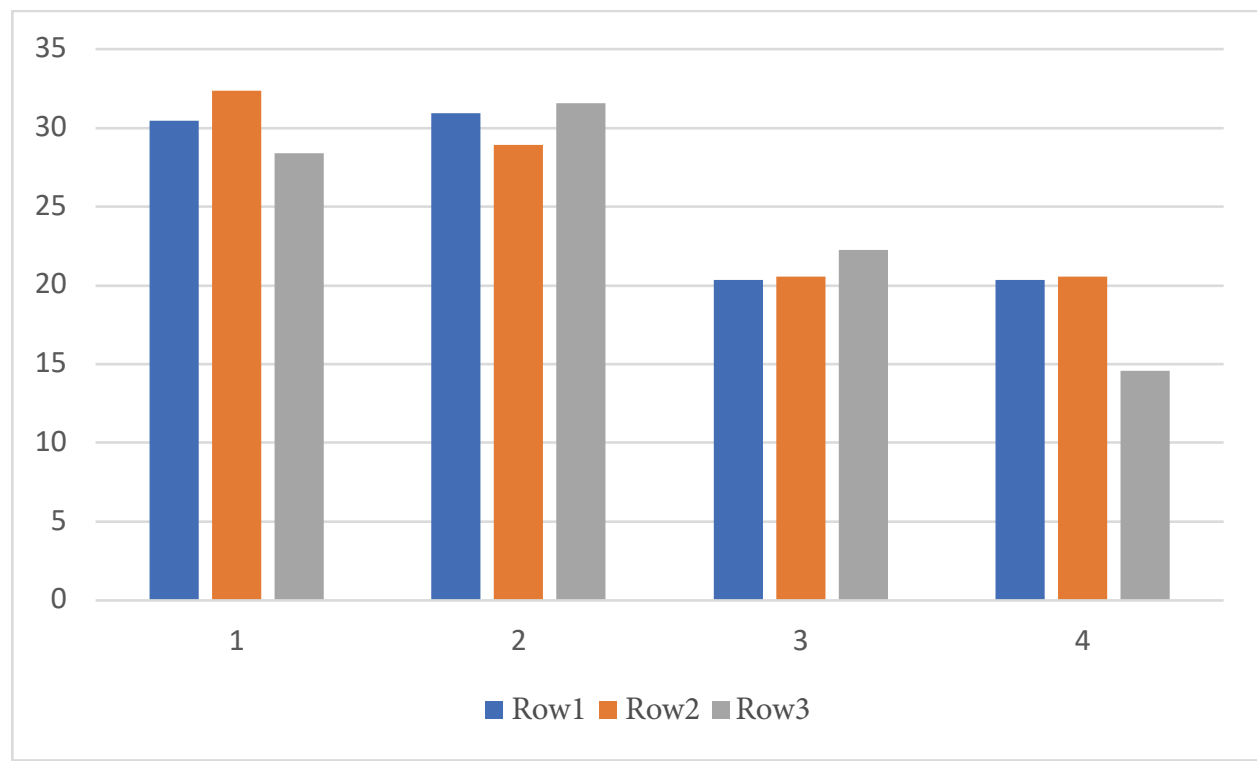

Fig. 1. Results of analysis of age-related dynamics of effort strength assessment in the boys aged 11-13 (bar 1 - 11 years, bar 2 - 12 years, bar 3 - 13 years; 1 - hand maximum strength, 2 - effort at $1 / 3$ of hand maximum strength, $\%, 3$ - effort at $1 / 2$ of hand maximum strength, $\%, 4$ - effort at $2 / 3$ of hand maximum strength, $\%$ )

boys of this age demonstrate the best assessment of effort at $2 / 3$ of the maximum (Table 2). A comparative analysis of the levels of ability for strength effort assessment in the boys aged 12 and 13 did not reveal statistically significant differences $(p>0.05)$. The boys of this age demonstrate the best assessment of effort at $2 / 3$ of the maximum (Table 3 ).

The boys aged 11 show $10.59 \%$ better assessment of effort at $1 / 2$ than effort at $1 / 3$ of the maximum $(p=0.006), 14.23 \%$ - effort at $2 / 3$ than effort at $1 / 3$ of the maximum $(p=0.006)$. There are no statistically significant differences in the assessment of efforts at $1 / 2$ and $2 / 3$ of the maximum. There are no statistically significant relationship between these indicators $\left(r_{12}=-0.111 ; r_{13}=-.021 ; r_{23}=.284 ; p>0.05\right)$ (Table 4, Fig. 1).

The boys aged 12 show $8.36 \%$ better assessment of effort at $1 / 2$ than effort at $1 / 3$ of the maximum $(p=0.007), 13.72 \%$ - effort at $2 / 3$ than effort at $1 / 3$ of the maximum $(p=0.001), 5.35 \%$ - effort at $2 / 3$ than effort at $1 / 2$ of the maximum $(p=0.032)$. There are no statistically significant relationship between these indicators $\left(r_{12}=-.126 ; r_{13}=.243 ; r_{23}=.048 ; p>0.05\right)$ (Table 5, Fig. 1).

The boys aged 13 show $9.32 \%$ better assessment of effort at $1 / 2$ than effort at $1 / 3$ of the maximum $(p=0.001), 16.97 \%$ - effort at $2 / 3$ than effort at $1 / 3$ of the maximum $(\mathrm{p}=0.001), 7.66 \%$ - effort at $2 / 3$ than effort at $1 / 2$ of the maximum $(p=0.001)$. There are no statistically significant relationship between these indicators $\left(r_{12}=.039 ; r_{13}=.075 ; r_{23}=-.107 ; p>0.05\right)$ (Table 6, Fig. 1).

\section{Discussion}

The study assumed that the schoolchildren had peculiarities in assessing efforts at 1/3,1/2 and $2 / 3$ of maximum strength. The study has found that there are no 
age-related changes in muscular effort assessment in the boys aged 11-13, which indicates that this age period is not sensitive to the development of the ability for strength effort assessment. The presented results supplement the data of Balsevich (2000), Ilin (2003), Liakh (2000) on the sensitive periods of movement coordination development in children and adolescents, and the data of Nosko (2002), Khudolii and Ivashchenko (2014) on motor function development in children and adolescents.

The boys aged 11-13 demonstrate the best assessment of effort at $2 / 3$ of maximum strength. These results confirm the data obtained by Ivashchenko (2016), Liakh (2000) showing that children and adolescents best assess efforts at $2 / 3$ of the maximum.

These findings confirm the conclusion made by Farfel (2011) that errors in the assessment of different modalities in motor control do not correlate with one another and require a special training for ages 11-13.

The revealed peculiarities of strength effort assessment in the boys aged 11-13 highlight the importance and practical significance of studying kinesthetic sensitivity and supplement the data of Li, Su, Fu and Pickett (2015), Brink and Jacobs (2011), Morash, Pensky, Alfaro and McKerracher (2012).

\section{Conclusions}

Boys aged 11-13 demonstrate the best assessment of effort at $2 / 3$ of maximum strength. There is no statistically significant age-related dynamics in strength effort assessment in boys aged 11-13. The correlation between the effort reproductions at $1 / 3,1 / 2$ and $2 / 3$ of the maximum is not statistically significant.

In the process of physical education of boys aged 11-13, special attention should be paid to the development of motor control ability as the component of coordination training of schoolchildren.

\section{Conflict of interest}

The author declares no conflict of interests.

\section{References}

Nosko, M.O., Iermakov, S.S., \& Harkusha, S.V. (2010).

Teoretyko-metodychni aspekty zmitsnennia fizychnoho zdorovia uchnivskoi ta studentskoi molodi. Visnyk Chernihivskoho natsionalnoho pedahohichnoho universytetu. Seriia: Pedahohichni nauky. Fizychne vykhovannia ta sport / Chernih. nats. ped. un-t im. T. H. Shevchenka. Chernihiv: Vyd-vo ChDPU, (76), 243-247.

Krutsevich, T. Yu. (2000). Upravlenie fizicheskim sostoyaniem podrostkov v sisteme fizicheskogo vospitaniya. K., 510.

Krutsevich, T.Yu. (2000). Prognoznye modeli garmonichnosti fizicheskogo razvitiya podrostkov. Pedagogika, psikhologiya ta mediko-biologichni problemi fizichnogo vikhovannya i sportu, (12) 48-55.
Ivashchenko, O.V. (2016). Modeliuvannia protsesu fizychnoho vykhovannia shkoliariv: Monohrafiia. Kharkiv: OVS.

Farfel, V. S. (2011). Upravlenie dvizheniiami v sporte. $M$. : Sovetskii sport, 202.

Serhiienko, L.P., Chekmarova, N.H., \& Khadzhynov, V.A. (2012). Psykhomotoryka: kontrol ta otsinka rozvytku : [Navchalnyi posibnyk]. Kharkiv : OVS, 270.

Balsevich, V.K. (2000). Ontokineziologiia cheloveka. M. : Teoriia i praktika fizicheskoi kultury, 275.

Ilin, E. P. (2003). Psikhomotornaia organizatciia cheloveka : ucheb. dlia vuzov. SPb. : Piter, 384.

Lopatiev, A., Ivashchenko, O., Khudolii, O., Pjanylo, Y., Chernenko, S., \& Yermakova, T. (2017). Systemic approach and mathematical modeling in physical education and sports. Journal of Physical Education and Sport (JPES), 17(1), 146-155.

Nosko, M. O. (2002). Problema udoskonalennia rukhovoi funktsii v protsesi navchannia. Pedahohika, psykholohiia ta medyko-biolohichni problemy fizychnoho vykhovannia i sportu: zb. nauk. pr. za red. S. S. Yermakova. Kh., (1), 19-31.

Krutsevych, T.Iu., Vorobiov, V. I., \& Bezverkhnia, H. V. (2011). Kontrol u fizychnomu vykhovanni ditei, pidlitkiv i molodi: navch. posib. K.: Olimp. l-ra, 224.

Liakh, V.I. (2000). Dvigatelnye sposobnosti shkolnikov: Osnovy teorii i metodiki razvitiia. M.: Terra-Sport, 192.

Liakh, V.I. (2001). Testy u fizicheskom vospitanii shkolnikov. M.: Fizkultura i sport, 114.

Khudolii, O.M. (2008). Zahalni osnovy teorii i metodyky fizychnoho vykhovannia: Navchalnyi posibnyk. Kharkiv: OVS.

Khudolii, O.M. \& Ivashchenko, O.V. (2014). Modeliuvannia protsesu navchannia ta rozvytku rukhovykh zdibnostei u ditei i pidlitkiv: Monohrafiia. Kharkiv: OVS, 320.

Bodnar, I., \& Andres, A. (2016). Tests and standards for express-control of physical fitness and health of middle school age pupils. Pedagogics, Psychology, Medical-Biological Problems of Physical Training and Sports, 20(4), 11-16. https://doi. org/10.15561/18189172.2016.0402

Ivashchenko, O. V., \& Kapkan, O. O. (2016). Informative pedagogic control indicators of 14-15 years age girls' motor fitness. Pedagogics, psychology, medical-biological problems of physical training and sports, 20(6), 18-25. https://doi.org/10.15561/18189172.2016.0603

Ivashchenko, O., Khudolii, O., Iermakov, S., \& Prykhodko, V. (2018). Coordinating abilities: recognition of a state of development of 11-13 years old boys. Pedagogics, Psychology, Medical-Biological Problems of Physical Training and Sports, 22(2), 86-91. https://doi. org/10.15561/18189172.2018.0204

Ivashchenko, O., Khudolii, O., Iermakov, S., Lochbaum, M., Cieślicka, M., Zukow, W., Nosko, M., \& Yermakova, T. (2017). Methodological approaches to pedagogical control of the functional and motor fitness of the girls from 7-9 grades. Journal of Physical Education and Sport (JPES), 17(1), 254-261. https://doi.org/10.7752/ jpes.2017.s1023 
Li, K., Su, W., Fu, H., \& Pickett, K. A. (2015). Kinesthetic deficit in children with developmental coordination disorder. Research in Developmental Disabilities, 38, 125-133. https://doi.org/10.1016/j.ridd.2014.12.013

Brink, A. O., \& Jacobs, A. B. (2011). Kinesthetic Sensitivity and Related Measures of Hand Sensitivity in Children With Nonproficient Handwriting. Pediatric Physical
Therapy, 23(1), 88-94. https://doi.org/10.1097/ PEP.0b013e318208cc81

Morash, V., Pensky, A. E. C., Alfaro, A. U., \& McKerracher, A. (2012). A Review of Haptic Spatial Abilities in the Blind. Spatial Cognition and Computation, 12(2-3), 83-95. https://doi.org/10.1080/13875868.2011.599901

\title{
РУХОВІ ЗДІБНОСТІ: ОСОБЛИВОСТІ ОЦІНКИ СИЛОВИХ ЗУСИЛЬ у ХЛОПЦІВ 11-13 РОКІв
}

\author{
Іващенко О.В. ${ }^{1}$, Цеслицька М. ${ }^{2}$, Носко М.O. ${ }^{3}$, Малишев Д.А. ${ }^{4}$ \\ ${ }^{1,4}$ Харківський національний педагогічний університет імені Г.С. Сковороди \\ ${ }^{2}$ Медичний колегіум: Бидгощ, Куявсько-Поморське воєводство \\ ${ }^{3}$ Національний університет «Чернігівський колегіум» імені Т.Г. Шевченка
}

Реферат. Стаття: 5 с., 4 табл., 20 джерел.

Мета дослідження - визначити особливості оцінки силових зусиль у хлопців 11-13 років.

Матеріал і методи. У дослідженні прийняли участь хлопців 11 років $(\mathrm{n}=22), 12$ років $(\mathrm{n}=31), 13$ років $(\mathrm{n}=33)$. Діти та їхні батьки були інформовані про всі особливості дослідження і дали згоду на участь в експерименті. У роботі використані методи аналізу наукової літератури, тестування, методи математичної статистики. Реєструвалися зусилля правої кисті 1/3, 1/2, 2/3 від максимального. Аналізувалася похибка в оцінці. Для визначення особливостей оцінки силових зусиль був використаний t-тест для парних спостережень і t-тест Стьюдента для незалежних виборок.

Результати. Аналіз рівня розвитку здібності до оцінки силових зусиль у хлопців 11 і 13 років виявив, що за всими показниками не спостерігається статистично значущих відмінностей між хлопцями зазначеного віку. Хлопці найкраще оцінюють зусилля 2/3 від макимального. У рівні розвитку максимальної сили кисті статистично достовірних розбіжностей не спостерігається $(p>0,05)$. У хлоп- ців 11 і 13 років статистично значущих розбіжностей у рівні розвитку здібності до оцінки силових зусиль не виявлено $(p>0,05)$, хлопці зазначеного віку краще оцінюють зусилля $2 / 3$ від максимального. Порівняльний аналіз рівня розвитку здібності до оцінки силових зусиль у хлопців 12 і 13 років не виявив статистично значущих розбіжностей $(p>0,05)$. Хлопці зазначеного віку краще оцінюють зусилля $2 / 3$ від максимального.

Хлопці 11-13 років найкраще оцінюють відтворення зусилля $2 / 3$ від максимального $(p<0,05)$. Статистично достовірної вікової динаміки в оцінці силових зусиль у хлопців 11-13 років не спостерігається. Взаємозв'язок між відтворенням зусилля $1 / 3,1 / 2$ та 2/3 від максимального статистично не достовірний.

Висновки. У процесі фізичного виховання хлопців 11-13 років необхідно акцентувати увагу на формування здібності до управління рухами як компоненти координаційної підготовки школярів.

Ключові слова: координація рухів, силові зусилля, управління рухами, хлопці 11-13 років.

\section{ДВИГАТЕЛЬНЫЕ СПОСОБНОСТИ: ОСОБЕННОСТИ ОЦЕНКИ СИЛОВЫХ УСИЛИЙ У РЕБЯТ 11-13 ЛЕТ}

\author{
Иващенко О.В. ${ }^{1}$, Цеслицька M. ${ }^{2}$, Носко Н.А. ${ }^{3}$, Малышев Д.А. ${ }^{4}$ \\ ${ }_{1,4}$ Харьковский национальный педагогический университет имени Г.С. Сковороды \\ ${ }^{2}$ Медицинский коллегиум: Быдгощ, Куявско-Поморское воеводство \\ ${ }^{3}$ Национальний университет «Черниговский коллегиум» имени Т.Г. Шевченко \\ Реферат. Статья: 5 с., 4 табл., 20 источников.
}

Цель исследования - определить особенности оценки силовых усилий в ребят 11-13 лет.

Материал и методы. В исследовании приняли участие ребята 11 лет $(\mathrm{n}=22), 12$ лет $(\mathrm{n}=31), 13$ лет $(\mathrm{n}=33)$. Дети и их родители были осведомлены обо всех особенностях исследования и дали согласие на участие в эксперименте. В работе использованы методы анализа научной литературы, тестирова- 
ние, методы математической статистики. Регистрировались усилия правой кисти $1 / 3,1 / 2,2 / 3$ от максимального. Анализировалась погрешность в оценке. Для определения особенностей оценки силовых усилий был использован t-тест для парных наблюдений и t-тест Стьюдента для независимых выборок.

Результаты. Анализ уровня развития способности к оценке силовых усилий у ребят 11 и 13 лет обнаружил, что за всеми показателям не наблюдается статистически значимых различий между ребятами указанного возраста. Ребята лучше оценивают усилия 2/3 макимального. В уровне развития максимальной силы кисти статистически достоверных различий не наблюдается $(p>0,05)$. У ребят 11 и 13 лет статистически значимых различий в уровне развития способности к оценке силовых усилий не обнаружено $(p>0,05)$, ребята указанного возраста лучше оценивают усилия 2/3 от максимального. Сравнительный анализ уровня развития способности к оценке силовых усилий у ребят 12 и 13 лет не выявил статистически значимых различий $(p>0,05)$. Ребята указанного возраста лучше оценивают усилия 2/3 от максимального.

Ребята 11-13 лет лучше оценивают воспроизведения усилия $2 / 3$ от максимального $(p<0,05)$. Статистически достоверной возрастной динамики в оценке силовых усилий в ребят 11-13 лет не наблюдается. Взаимосвязь между воспроизведением усилия $1 / 3,1 / 2$ и 2/3 от максимального статистически не достоверна.

Выводы. В процессе физического воспитания ребят 11-13 лет необходимо акцентировать внимание на формирование способности к управлению движениями как компоненты координационной подготовки школьников.

Ключевые слова: координация движений, силовые усилия, управление движениями, ребята 11-13 лет.

\section{Information about the authors:}

Ivashchenko O.V.: olga@tmfv.com.ua; https://orcid.org/0000-0002-2708-5636; Department of Theory and Methodology of Physical Education, Health and Medical Physical Culture, H. S. Skovoroda Kharkiv National Pedagogical University, Alchevskikh St, 29, Kharkiv, 61002, Ukraine.

Cieślicka M.: cudaki@op.pl; https://orcid.org/0000-0002-0407-2592; Collegium Medicum: Bydgoszcz, kujawsko pomorskie, Chodkiewicza St, 30, 85-064 Bydgoszcz, Poland.

Nosko M.O.: chnpu@chnpu.edu.ua; https://orcid.org/0000-0001-9903-9164; Department of Pedagogy, Psychology and Methodology of Physical Education, Taras Shevchenko National University of "Chernihiv Collegium", Hetman Polubotka St, 70, Chernihiv, Chernigov region, 14000, Ukraine.

Malyshev D. A.: https://orcid.org/0000-0003-1407-6148; Department of Theory and Methodology of Physical Education, Health and Medical Physical Culture, H. S. Skovoroda Kharkiv National Pedagogical University, Alchevskikh St, 29, Kharkiv, 61003, Ukraine.

Cite this article as: Ivashchenko, O.V., Cieślicka, M., Nosko, M.O., \& Malyshev, D. A. (2019). Motor Abilities: Peculiarities of Strength Effort Assessment in Boys Aged 11-13. Teoriâ ta Metodika Fizičnogo Vihovannâ, 19(1), 37-43. https://doi.org/10.17309/tmfv.2019.1.05

Received: 10.02.2019. Accepted: 20.03.2019. Published: 25.03.2019

This work is licensed under a Creative Commons Attribution 4.0 International License (http://creativecommons.org/ licenses/by/4.0). 